\title{
Bachelor of Education in Service Teacher Trainees' Perceptions and Attitudes on Inclusive Education in Zimbabwe
}

\author{
Mandina Shadreck ${ }^{1}$ \\ ${ }^{1}$ Department of Educational Foundations, Management and Curriculum Studies, Midlands State University, \\ Gweru, Zimbabwe \\ Correspondence: Mandina Shadreck, Department of Educational Foundations, Management and Curriculum \\ Studies, Midlands State University, P Bag 9055 Gweru, Zimbabwe. Tel: 263-54-260-464. E-mail: \\ mandinas@msu.ac.zw; mandinashadreck@yahoo.com
}

\author{
Received: March 15, 2012 Accepted: July 3, 2012 Online Published: October 19, 2012 \\ doi:10.5539/ass.v8n13p227 URL: http://dx.doi.org/10.5539/ass.v8n13p227
}

\begin{abstract}
The purpose of this study was to investigate inclusion and the perceptions and attitudes that Bachelor of Education in service trainee teachers hold towards inclusive education in Zimbabwe. The participants were 97 main stream in-service Bachelor of Education teacher trainees (43 male, 54 female) from Midlands State University's Faculty of Education. The research design was exploratory and descriptive in nature. A questionnaire was used for data collection. The findings indicate that main stream trainee teachers believe that children with severe disabilities would benefit from being in an inclusion class however the main stream teachers feel that their college training is not sufficient enough to equip them to teach in an inclusion setting, especially those children with severe disabilities and emotional and behavioral problems. The findings also indicate that main stream trainee teachers in Zimbabwe have somewhat negative attitudes towards inclusive education. The teachers noted that large class sizes, inadequate resources and facilities and lack of support as challenges militating against the implementation of inclusive education. Recommendations on the improvement of inclusive education in Zimbabwe especially on the need for increased support from the government and the private and public sector in terms of funding to purchase equipment and resource facilities as well as upgrading of infrastructure and teacher training to make inclusive education a success in Zimbabwe were made.
\end{abstract}

Keywords: inclusive education, children with disabilities, teacher training, mainstream teachers, Zimbabwe

\section{Introduction}

Inclusive education, in its broader sense, is about acknowledging diversity of learners' needs and providing appropriate support. This happens when the education system is characterized by a shared responsibility among all the stakeholders to collaboratively provide a continuum of specialized support to address different needs of all learners. The needs range from cognitive, physical, emotional and cultural needs just to mention a few of them. Learners in the inclusive system therefore take a full and active part and are perceived as the full members of the institution as well as classroom community. Ajuwon (2012) notes that the basis of inclusion is that special needs pupils have a right to the benefits of a full school experience, with needed modifications and support, alongside their peers without disabilities who receive general education. Thus it is about creating a welcoming and supportive institutional culture that accepts and respects diversity of learners unconditionally. In inclusive education the whole system is custom-made; this includes curriculum and assessment standards, to meet the needs of learners not the predetermined needs of the curriculum (Stewart, 1983).

Given that the ultimate goal of inclusion is to create schools with prepared teachers that recognize all students have a right to participate in all aspects of the school community environment, teacher training institutions must provide the education necessary for effective implementation of inclusionary practices (Swain et al, 2012). Teachers are thus perceived to be integral to the implementation of inclusive education (Haskell, 2000). Research has shown the view that teachers are the key to the success of inclusionary programs as they are viewed as linchpins in the process of including students with disabilities into regular classes (Unianu, 2011). Other studies acknowledge that inclusive education can only be successful if teachers are part of the team driving this process (Malone et al, 2001).

It is important to examine the attitudes of mainstream educators toward the inclusion of students with disabilities into regular settings as their perceptions may influence their behavior toward and acceptance of such students 
(Hammond \& Ingalls, 2003; Van Reusen et al, 2001). The success of an inclusionary program may be at risk if regular classroom teachers hold negative perceptions toward the inclusion of students with disabilities (Van Reusen et al., 2001). Negative perceptions of inclusive education may become obstacles, as general education teachers attempt to include students with disabilities (Cawley et al, 2002).

One prominent strand of research on teachers' value systems is the study of teachers' attitudes towards inclusive education (Savolainen et al, 2012). Attitudes are usually seen as relatively stable constructs containing cognitive, affective and behavioural element, but findings also show that even short-term training can have positive effects on attitudes (Beachman and Rouse, 2011). Ahmmed et al (2012) posit that teachers' attitudes towards inclusion are often not based on ideological arguments, but rather on practical concerns about how inclusive education can be implemented. More recently there has been a growing interest of studying this pragmatic side of teaching by measuring teachers' feelings of self-efficacy in implementing inclusive education. Cologon (2011) has provided evidence to support the idea that there is a positive relationship between teacher self-efficacy and attitudes toward inclusive education.

Zimbabwe is a signatory to several inclusive education-related international charters and conventions such as the Salamanca statement and framework for action on special needs education (UNESCO 1994). The Zimbabwean 1987 Education Act, revised in 2006, specifies that there should be inclusion of Children with Special Needs (CSN) into regular schools. In addition the Zimbabwean Education Act introduced free and compulsory education for all students regardless of any demographic differences implying support for inclusive education. International studies on the attitudes of teachers including trainee teachers towards inclusive education have been conducted (Loreman et al. 2007, Lambe and Bones 2007, Avramidis et al. 2000). Findings from these studies do indicate that in most cases, trainee teachers had negative attitudes towards inclusive education with female trainee teachers having more favorable attitudes. The trainee teachers were reported to have developed positive attitudes towards the principle of inclusion as a result of exposure to children with disabilities. Local studies on inclusive education have focused on attitudes of trained teachers towards inclusive education (Maunganidze and Kasayira 2002; Mushoriwa 2002a), special needs education (SNE) trainee teachers (Chireshe, 2011). However, not much research has been done on views of mainstream trainee teachers on the inclusive education at the secondary level hence the need for this study. This study sought to establish Bachelor of Education in service teacher trainees' views about inclusive education in Zimbabwe. Bachelor of Education in service trainee teachers are key stakeholders in the education sector who will be involved in the implementation of inclusive education and their views should not be ignored. Their views would be used to improve the implementation of inclusive education. The purpose of this study was to investigate inclusion and the perceptions and attitudes that Bachelor of Education in service trainee teachers hold towards inclusive education in Zimbabwe.

\section{Research Questions}

The study sought to answer the following main research question: What are the perceptions and attitudes that Bachelor of Education in service trainee teachers hold towards inclusive education in Zimbabwe.

The following research questions were set forth by the researcher:

1) Is inclusive education the most appropriate academic setting for children with special needs?

2) Are the mainstream education teachers being trained appropriately to en campus inclusion?

3) Do in service trainee teachers hold a positive or negative attitude towards inclusive education?

4) What are the perceived implementation challenges faced with inclusion?

\section{Research Methodology}

\subsection{Research Design}

The study employed the descriptive survey method. This method focused on systematic description or exposure of the salient aspects of a situation with a focus on the patterns that emerge. The study was analytic (qualitative) in that the researchers focused on the relationships between variables and further interpreted the relationships. The survey design was preferred because it is the most appropriate design where self-reported beliefs and opinions of participants are sought (David and Sutton 2004).

\subsection{Sample}

Ninety - seven (43 male and 54 female) Midlands State University Bachelor of Education teacher trainees participated in the study. They were enrolled in a two -year Bachelor Education program. Their teaching experiences ranged from 2 to over 8 years. Participants volunteered to take part in the study. 


\subsection{Research Instruments}

A questionnaire was used as it was found to be the most ideal data collecting instrument for the relatively large sample (Tuckman, 1994). The questionnaire had both closed and open- ended items. Questions were meant to solicit information from Bachelor of Education students on their perceptions and attitudes towards inclusive education in Zimbabwe. The questionnaire was validated by two experts who had been practicing inclusive education for more than six years.

\subsection{Data Collection Procedure.}

The research was conducted at Midlands State University with Bachelor of Education students. The researcher explained the purpose of the study to potential participants (Midlands State University Bachelor of Education students). After the explanation, volunteers were invited to fill in the questionnaire. Out of the 97 questionnaires distributed, 90 usable responses were returned (92.8\% response rate). Data were collected over a six month period in 2011.

\subsection{Data Analysis}

Data was analyzed using The SPSS- version 18.1. The data obtained were presented in tables and descriptive analysis, frequencies and percentages were used. Qualitative responses from open-ended items reflecting the same themes were grouped together.

\section{Results}

\subsection{Do Children with Severe Disabilities Benefit Academically from Inclusion}

The first question the researcher wanted answered was if teachers thought that children with special needs or with severe disabilities would benefit academically in an inclusion class. Ninety percent (81) of teachers strongly agreed that students who are severely disabled would benefit academically from an inclusion class. Five teachers (6\%) agreed that children with disabilities would not benefit from being in an inclusion class while $4 \%$ were uncertain. The results indicate that the majority of teachers agree that children with severe disabilities would benefit from being in an inclusion class.

\subsection{Are Mainstream Teachers Trained Enough to Teach Children with Disabilities?}

The second question the researchers wanted to investigate was if teachers believe that they were trained enough to teach children with disabilities. This question asked if teachers feel college level training is sufficient for them to teach in an inclusion class. Most teachers agree that college level training is not sufficient to equip them to teach in an inclusion setting, especially those children with severe disabilities and emotional and behavioral problems. Ninety eighty percent of teachers disagree with the fact that college level courses prepared them sufficiently to teach in an inclusion setting while $2 \%$ of teachers feel that college level courses are sufficient enough to be placed into an inclusion classroom. Thus most teachers do not think that they have enough training to teach those with special needs.

\subsection{Do Bachelor of Education Trainee Teachers Hold a Positive or Negative Attitude towards Inclusive Education?}

The third question the sought to investigate if teachers had a negative attitude toward inclusion. This was done by a series of question regarding inclusion and its possible benefits. The researcher asked if a teacher would accept an inclusion job if offered one. The majority of the teachers (97\%) disagreed with the job opportunity of teaching an inclusion class which indicated that they would not accept the job while $3 \%$ said they would take up the job. The ones that agreed had done a special education course. The majority of teachers thus would not accept an inclusion teaching job an indication that they could be having more negative attitudes toward inclusion than positive.

\subsection{What Are the Perceived Implementation Challenges Faced with Inclusion?}

The last question investigated the challenges teachers are facing in the implementation of inclusive education. The teachers noted that large class sizes, inadequate resources and facilities and lack of support as challenges militating against the implementation of inclusive education.

\section{Discussion}

The study revealed that teacher trainees felt that children with severe disabilities would benefit academically from being in an inclusive class. The findings are in agreement with several research studies that have shown that the inclusion of students with severe disabilities into general education settings is beneficial for all students (those with and without disabilities) particularly in relation to social acceptance, self-esteem, and social skills 
(Kennedy, Shukla, \& Fryxell, 1997; Mu, Siegel, \& Allinder, 2000). Not only do individuals with severe disabilities learn as a result of direct instruction (Browder et al. 2008), but they also learn through observation of fellow learners without disabilities (Falkenstine et al. 2009). These students with severe disabilities do benefit both academic and nonacademic skills when they are given quality instruction and support. While research has indicated these academic gains, however teachers are more challenged to appropriately include students with severe disabilities in the content areas and related academic subjects.

The majority of the teachers perceived themselves as unprepared for inclusive education because they lack appropriate training in this area. Schumm et al (1994) point out that inadequate training relating to inclusive education, may result in lowered teacher confidence as they plan for inclusive education. Teachers who have not undertaken training regarding the inclusion of students with disabilities, may exhibit negative attitudes toward such inclusion (Van Reusen et al., 2001), while increased training is associated with more positive attitudes toward the inclusion of students with disabilities (Powers, 2002). Training in the field of special education appears to enhance understanding and improve attitudes regarding inclusion (Kuester, 2000; Powers, 2002). The students also felt that the introductory course in special needs education offered at the institution is inadequate in preparing the general educator for successful inclusion. The findings from this study validates findings by Dew-Hughes and Brayton (1997) who noted a discrepancy between mainstream teacher preparation for meeting special needs in the classroom, and the reality which they face in the schools with most teachers arguing that their college training had not prepared them for the diversity and dimension of special needs in mainstream schools.

The findings of this study also show that mainstream trainee teachers have a negative attitude towards inclusion. This mainly stems from inadequate training in inclusive education and lack of confidence to teach in an inclusive environment. The findings from the study affirms findings by Van Reusen et al (2001) who found out that teachers who have not undertaken training regarding the inclusion of students with disabilities, may exhibit negative attitudes toward such inclusion while increased training was associated with more positive attitudes toward the inclusion of students with disabilities. Hence training in the field of special education appears to enhance understanding and improve attitudes regarding inclusion. Furthermore the lack of confidence among the trainee teacher to take up a job in an inclusive environment is also a contributor to the negative attitudes towards inclusion as noted by Avramidis et al. (2000) who concluded that mainstream educators generally lacked confidence as they attempted to include students with disabilities into their classes. This may be as a result of lacking proficiency about modifying the regular education curriculum to suit students with individual learning needs. Pursuant to this, Briggs et al (2002) also note that teachers who perceive themselves as competent inclusive educators, often have more positive attitudes toward inclusive education. Teachers acquire increased competence as a result of increased training in the field of inclusive education (Avramidis et al., 2000). Inadequate knowledge with regard to instructional techniques and curricular adaptations, which contributes to decreased confidence, may be factors which influence a teacher's attitude toward inclusive education.

Further the teachers lament overcrowded classrooms, lack of prepared teaching materials, inflexible time table, inadequate time for planning and meeting, and inadequate specialist support in schools as factors acting against the successful implementation of inclusive education. In addition, teachers showed concern about inadequate equipment and the availability of paraprofessionals in schools serving students with disabilities. They were concerned about the provision of resources and funding to support students with disabilities in mainstream settings. These findings are consistent with studies reported by Hammond and Ingalls, (2003) on the need for support of teacher as critical in order for them to implement inclusive practices. Large classes were also viewed as an obstacle to the successful implementation of inclusive education. As noted by Van Reusen et al (2001), larger classes place additional demands on the regular educator, while reinforcing concern that all students may not receive proper time or attention.

\section{Limitation of the Study}

The participants are a sample of Bachelor of Education in service teacher trainees attending one national state university, and thus, are not representative of all Bachelor of Education in service teacher trainees throughout the country. A larger sample representative of all state and private universities that currently offer Bachelor of Education in service teacher training in the country would be recommended.

\section{Conclusion}

The purpose of this study was to investigate inclusion and the perceptions and attitudes that Bachelor of Education in service trainee teachers hold towards inclusive education in Zimbabwe. The findings indicate trainee teachers in Zimbabwe have somewhat negative attitudes about inclusive education. Most of the teachers are particularly concern about the fact that they are not adequately prepared/ trained to teach students with 
disabilities in regular classes and thus lack confidence and display negative attitudes toward inclusive education.

\section{Recommendations}

Based on the findings of this study the researcher recommends that the education and training of mainstream teachers to work with students with disabilities should be improved to ensure that teachers have the necessary skills to teach such students. The Ministry of Education should organize in-service teacher workshops that address the skill development necessary to cater to the needs of children with disabilities in inclusive settings. Finally there is need for increased support from the government and the private and public sector in terms of funding to purchase equipment and resource facilities as well as upgrading of infrastructure to make inclusive education a success in Zimbabwe.

Future research should examine the relation between the introduction of courses inclusive education and changes in attitudes toward inclusive education and the likelihood of in service teachers majoring in special education.

\section{References}

Ahmmed, M., Sharma, U., \& Deppeler, J. (2012), Variables affecting teachers' attitudes towards inclusive education in Bangladesh. Journal of Research in Special Educational Needs. http://dx.doi.org/10.1111/j.1471-3802.2011.01226.x

Ajuwon, P. M. (2012). Making Inclusive Education Work in Nigeria: Evaluation of Special Educators' Attitudes. Disability Studies Quarterly, 32(2).

Avramidis, E., Bayliss, P., \& Burden, R. (2000). A survey into mainstream teachers' attitudes towards the inclusion of children with special educational needs in the ordinary school in one local education authority. Educational Psychology, 20(2), 191-121. http://dx.doi.org/10.1080/713663717

Beacham, N., \& Rouse, M. (2012). Student teachers' attitudes and beliefs about inclusion and inclusive practice. Journal of Research in Special Educational Needs, 12, 3-11. http://dx.doi.org/10.1111/j.1471-3802.2010.01194.x

Briggs, J. D., Johnson, W. E., Shepherd, D. L., \& Sedbrook, S. R. (2002). Teacher Attitudes and Attributes concerning Disabilities. Academic Exchange Quarterly, 6(2), 85-89. Retrieved January 9, 2009, from http://www.highbeam.com/doc/1G1-89970440.html

Browder, D. M., Spooner, F., Ahlgrim-Delzel, L., Harri, A., \& Wakeman, S. (2008). A meta-analysis on teaching mathematics to students with significant cognitive disabilities. Exceptional Children, 74(4), 407-432. Retrieved March 8, 2012, from http://www.eric.ed.gov/ERICWebPortal/detail?accno=EJ817542

Cawley, J., Hayden, S., Cade, E., \& Baker-Kroczynski, S. (2002). Including students with disabilities into the general education science classroom. Exceptional Children, 68(4), 423-435. Retrieved July 5, 2010, from $\mathrm{http}: / /$ www.library.gatech.edu:2048/login?url=http://search.ebscohost.com/login.aspx?direct=true\&db=a9h $\& \mathrm{AN}=6927572 \&$ site $=$ ehost-live

Chireshe, R. (2011). Special Needs Education In-Service Teacher Trainees' Views on Inclusive Education in Zimbabwe. Journal of Social Sciences, 27(3), 157-164. Retrieved November 7, 2011, from http://www.krepublishers.com/.../JSS-27-3-157-11-1194-Chireshe-R-Tt.pdf

Cologon, K. (2011). Confidence in their own ability: postgraduate early childhood students examining their attitudes towards inclusive education. International Journal of Inclusive Education, iFirst Article, 1-19. http://dx.doi.org/10.1080/13603116.2010.548106

Dew-Hughes, D., \& Brayton, H. (1997). Initial Teacher Training and Pupils with Special Educational Needs. Support for Learning, 12, 175-179. http://dx.doi.org/10.1111/1467-9604.00041

Falkenstine, K. J., Collins, B. C., Schuster, J. W., \& Kleinert, H. (2009). Presenting chained and discrete tasks as non-targeted information when teaching discrete academic skills through small group instruction. Education and Training in Developmental Disabilities, 44(1), 127-142. Retrieved March 5, 2009, from $\mathrm{http}: / /$ www.eric.ed.gov/ERICWebPortal/detail?accno=EJ864628

Hammond, H., \& Ingalls, L. (2003). Teachers attitudes toward inclusion: Survey results from elementary school teachers in three Southwestern rural school districts. Rural Special Education Quarterly, 22(2), 24-30. Retrieved May 12, 2009, from http://www.highbeam.com/doc/1P3-503694881.html

Haskell, D. H. (2000). Building bridges between Science and Special Education. Electronic Journal of Science Education., 4(3). Retrieved September 14, 2008, from http://www.eric.ed.gov /ERICWebPortal/detail?accno=EJ651179 
Kuester, V. M. (2000). 10 Years on: Have teacher attitudes toward the inclusion of students with disabilities changed? Paper presented at the ISEC 2000, London. Retrieved October 18, 2009, from http://www.isec2000.org.uk/abstracts/papers_k/kuester_1.htm

Lambe, J., \& Bones, R. (2006). Student teachers' perceptions about inclusive classroom teaching in Northern Ireland prior to teaching practice experience. European Journal of Special Needs Education, 21(2), 167-186. http://dx.doi.org/10.1080/08856250600600828

Loreman, T., Forlin, C., \& Sharma, U. (2007). An International Comparison of Pre-service Teacher Attitudes Towards Inclusive Education. Disability Studies Quarterly, 24(4). Retrieved January 23, 2012, from http://www.dsq-sds.org/article/views/53/53

Malone, D. M., Gallagher, P. A., \& Long, S. R. (2001). General education teachers' attitudes and perceptions of teamwork supporting children with developmental concerns. Early Education and Development, 12(4), 577-592. http://dx.doi.org/10.1207/s15566935eed1204_5

Maunganidze, L., \& Kasayira, J. M. (2002). Educational integration of children with disabilities in schools in the Midlands region of Zimbabwe. The Zimbabwean Bulletin of Teacher Education, 11(1), 72-82.

Mushoriwa, T. D. (2002a). At odds with inclusive education. The Zimbabwean Bulletin of Teacher Education, $11(1), 83-91$.

Powers, S. (2002). From concepts to practice in deaf education. Journal of Deaf Studies and Deaf Education, 7(3), 230-243. http://dx.doi.org/10.1093/deafed/7.3.230

Savolainena, H., Engelbrecht, P., Nel, M., \& Olli-Pekka, M. (2012). Understanding teachers' attitudes and self-efficacy in inclusive education: implications for pre-service and in-service teacher education. European Journal of Special Needs Education, 27(1), 51-68. http://dx.doi.org/10.1080/08856257.2011.613603

Schumm, J. S., Vaughn, S., Gordon, J., \& Rothlein, L. (1994). General Education Teachers' Beliefs, Skills and Practices in Planning for Mainstreamed Students with Learning Disabilities. Teacher Education and Special Education, 17(1), 22-37. http://dx.doi.org/10.1177/088840649401700104

Stewart, F. K. (1983). Teacher attitudes and expectations regarding mainstreaming of handicapped children. Teacher Education and Special Education, 6(1), 39-45. http://dx.doi.org/10.1177/088840648300600107

Swain, K. D., Nordness, P. D., \& Leader-Janssen, E. M. (2012). Changes in Preservice Teacher Attitudes Toward Inclusion, Preventing School Failure. Alternative Education for Children and Youth, 56(2), 75-81. http://dx.doi.org/10.1080/1045988X.2011.565386

Unianu, E. M. (2011). Teachers' attitudes towards inclusive education. Procedia-Social and Behavioral Sciences, 33, 900-904. http://dx.doi.org/10.1016/j.sbspro.2012.01.252

Van Reusen, A. K., Shoho, A. R., \& Barker, K. S. (2001). High School Teacher Attitudes toward Inclusion. The High School Journal, 84(2), 7-17. Retrieved August 12, 2007, from http://www.jstor.org/stable/40364402

Villa, R. A., Thousand, J. S., Meyers, H., \& Nevin, A. (1996). Teacher and administrator perceptions of heterogenous education. Journal of Exceptional Children, 63(1), 29-45. Retrieved September 6, 2009, from http://www.eric.ed.gov/ERICWebPortal/recordDetail?accno=EJ529421 